\title{
Murine Antiidiotypic Monoclonal Antibodies that Bear the Internal Image of HLA-DR Allospecificities
}

\author{
Federico Perosa and Soldano Ferrone \\ New York Medical College, Department of Microbiology and Immunology, Valhalla, New York 10595
}

\begin{abstract}
Hybridization of murine myeloma cells P3-X63-Ag8.653 with splenocytes from a BALB/c mouse immunized with the syngeneic anti HLA-DR1,4,w6,w8,w9 MAb AC1.59 resulted in the development of 108 hybridomas secreting antiidiotypic antibodies. 100 of them inhibited the binding of MAb AC1.59 to target cells. Detailed analysis of the antiidiotypic MAb F5-444, F5-830, F5-963, F5-1126, F5-1336, and F5-1419 showed that all of them recognize idiotopes within or spatially close to the antigen combining site of MAb AC1.59. In crossblocking experiments, the six antiidiotypic MAbs crossblocked each other. It is likely that the six MAbs recognize spatially close, but not identical idiotopes because they elicited antiantiidiotypic antibodies of different or similar, but not identical specificity and differ in their ability to elicit anti-HLA class II antibodies. The latter, which were found only in sera from BALB/c mice immunized with antiidiotypic MAb F5-444 and F5-830, mimic the specificity of MAb AC1.59 and express the idiotope defined by the immunizing antiidiotypic MAb. These results indicate that the MAb F5-444 and F5-830 are antiidiotypes $\beta$ and the remaining four are antiidiotypes $\gamma$.
\end{abstract}

\section{Introduction}

Jerne's network theory postulates that idiotypic interactions regulate the immune system (1). In agreement with this theory, antiidiotypic antibodies raised to antibodies to a variety of antigens have been shown to be useful reagents with which to manipulate the immune response to the corresponding antigens, presumably by balancing amplification and suppressor signals among immune cell subsets (2-5). These approaches have been greatly facilitated by hybridoma methodology, which has provided homogeneous antibodies to be used as immunogens and as targets to elicit and to characterize antiidiotypic antibodies, respectively. Furthermore, hybridoma methodology has overcome the practical difficulties inherent in preparing large amounts of purified and well-standardized antiidiotypic antibodies with a well-defined specificity.

Despite the regulatory role of HLA class II antigens in immunological phenomena, of the availability of anti-HLA class II MAbs and the potential applications of antiidiotypic antibodies to anti-HLA class II antibodies to investigate and to

Address reprint requests to Dr. Soldano Ferrone, Department of Microbiology and Immunology, New York Medical College, Valhalla, NY 10595.

Received for publication 1 February 1989.

J. Clin. Invest.

(C) The American Society for Clinical Investigation, Inc. 0021-9738/89/09/0907/08 $\$ 2.00$

Volume 84, September 1989, 907-914 modulate the immune response to these antigens, to the best of our knowledge, antiidiotypic MAbs to anti-HLA class II antibodies have not yet been developed. We therefore attempted to produce antiidiotypic MAbs to murine anti-HLA class II MAbs and to determine which of these could mimic the immunogenic epitope of HLA class II alloantigens. The aim of this paper is to characterize the specificity and the functional characteristics of six syngeneic antiidiotypic MAbs elicited with the murine MAb AC1.59, which recognizes a determinant expressed on HLA-DR 1,DRw8,DRw9 allospecificities and on subtypes of HLA-DR4 and DRw6 allospecificities (6).

\section{Methods}

Animals. Eight 12-wk-old BALB/c mice were purchased from Charles River Breeding Laboratories, Wilmington, MA.

Cell lines. The HLA homozygous cultured B lymphoid cells BAE 219 (HLA-DR8), LG-2 (HLA-DR1), LKT-13 (HLA-DR4), MANN (HLA-DR7), THO (HLA-DR4), WALK (HLA-DR4), WT49 (HLADR3), and Yallup (HLA-DR8); the HLA heterozygous cultured B lymphoid cells Victor (HLA-DR4,w6) and WI-L2 (HLA-DR4,7); the cultured T lymphoid cells MOLT-4; and the murine myeloma cells P3-X63-Ag8.653 were grown in medium RPMI 1640 supplemented with $10 \%$ FCS, $2 \mathrm{mM} \mathrm{L-glutamine,} \mathrm{and} 25 \mu \mathrm{g} / \mathrm{ml}$ gentamicin sulfate.

$M A b s$ and conventional antisera. The anti-HLA class I, anti-HLA class II and anti-human melanoma-associated antigen (MAA) ${ }^{1}$ MAbs developed in our laboratory were prepared and characterized as described elsewhere (6-15). The anti HLA-DP MAb B7/21 and the anti HLA-DR1 MAb H40-242.3 were developed as described $(16,17)$.

The murine antiidiotypic MAb F3-C25 and F3-B6 to idiotopes within (or closely related to) and outside the antigen combining site, respectively, of the syngeneic anti HLA-DR,DP MAb CR11-462 (18) and the murine antiidiotypic MAb T10-440 to an idiotope within (or closely related to) the antigen combining site of the syngeneic antiHLA-A2,A28 MAb CR1 1-351 (Ferrone, S., unpublished observations) have been prepared and characterized following procedures similar to the ones we have used in this investigation.

MAbs were purified from ascitic fluid by a two-step procedure. After caprylic acid (19) or $40 \%$ ammonium sulfate precipitation, IgM were purified by gel filtration on a fast-phase liquid chromatography (FPLC) system (Pharmacia Fine Chemicals, Piscataway, NJ), IgG1 by ion exchange chromatography on DEAE and IgG2 by affinity chromatography on protein A Sepharose (Pharmacia Fine Chemicals) (20). $F\left(a b^{\prime}\right)_{2}$ fragments were prepared from IgG1 MAbs following the procedure we have previously applied (21). The purity of the whole Ig and of $\mathrm{F}\left(\mathrm{ab}^{\prime}\right)_{2}$ fragments of MAbs was assessed by SDS-PAGE (22).

Affinity-purified goat antibodies to the Fc portion of murine IgG and to the heavy and light chain of murine IgG and IgM were purchased from Jackson Immunoresearch Laboratories (Avondale, PA). Antibodies were radiolabeled with ${ }^{125}$ I using the chloramine $T$ method (23).

Preparation of syngeneic antiidiotypic MAbs to MAb AC1.59. A BALB/c mouse was primed with an intraperitoneal injection of $200 \mu \mathrm{g}$ of purified MAb AC1.59 that had been coupled to keyhole limpet

1. Abbreviations used in this paper: IEF, isoelectric focusing; IFA, incomplete Freund's adjuvant; MAA, melanoma-associated antigen. 
hemocyanin (KLH) (Sigma Chemical Co., St. Louis, MO), polymerized with glutaraldehyde (24) and mixed with CFA (Gibco Laboratories, Grand Island, NY). The mouse was then boosted with $200 \mu \mathrm{g}$ of the same immunogen in incomplete Freund's adjuvant (IFA) on days $7,12,21,51,58$, and 65 . On day 79 the mouse was killed, the spleen was removed, and splenocytes were hybridized with murine myeloma cells P3-X63-Ag8.653. Hybridization and subcloning were performed according to standard procedures. The isotype of MAbs was determined by testing either spent medium of hybridomas with mouse monoclonal subisotyping kit (model 55051; Hyclone Laboratories, Logan, UT) in ELISA or 10-20-fold-concentrated spent medium with xenoantibodies specific for murine Ig classes and subclasses (Zymed Laboratories, Inc., San Francisco, CA) in radial immunodiffusion.

Preparation of syngeneic antiantiidiotypic antisera. Six groups of four BALB/c mice each were immunized by an intraperitoneal injection of $200 \mu \mathrm{g}$ of purified antiidiotypic MAbs F5-444, F5-830, F5-963, F5-1126, F5-1336 and F5-1419 coupled to KLH, polymerized with glutaraldehyde, and mixed with CFA. Mice were then boosted with $200 \mu \mathrm{g}$ of the same immunogen in IFA on days 7 and 14. Serum was harvested on day 14 before the booster, 45 and 65 .

Idiotype binding assays. They were performed in polyvinylchloride microtiter plates (Dynatech Laboratories, Alexandria, VA). The indirect binding assay with ${ }^{125}$ I-labeled xenoantibodies to the $\mathrm{Fc}$ fragment of murine $\mathrm{IgG}$, the direct binding assay with ${ }^{125}$ I-labeled antiidiotypic MAbs, and the inhibition by antiidiotypic MAbs of the binding of anti-HLA MAbs to lymphoid cells were performed as described elsewhere (25).

Cross-inhibition experiments were performed by incubating MAb AC1.59-coated plates with $50 \mu \mathrm{l}$ of fourfold dilutions of cold antiidiotypic MAbs (concentration ranging between 200 and $0.04 \mu \mathrm{g} / \mathrm{ml}$ ) for 7 $\mathrm{h}$ at $4^{\circ} \mathrm{C}$. After four washings with PBS-Tween 20, plates were incubated with ${ }^{125}$ I-labeled antiidiotypic MAbs $\left(1 \times 10^{5} \mathrm{cpm} /\right.$ well $)$. The assay was then continued as described above for the binding assay. Negative controls were performed by incubating MAb AC1.59-coated plates with antiidiotypic MAbs to an unrelated MAb. Positive controls were performed by incubating MAb AC1.59-coated plates with an antiidiotypic MAb homologous to the ${ }^{125}$ I-labeled one.

Competition experiments were performed by preincubating radiolabeled MAb with cold MAb for $2 \mathrm{~h}$ at $4^{\circ} \mathrm{C}$ before incubation for $16 \mathrm{~h}$ at $4^{\circ} \mathrm{C}$ with $\mathrm{MAb}$-coated microtiter plates.

Results are expressed as percent of inhibition compared with negative controls. The results obtained with the cross-inhibition assay and with the competition assay are superimposable. Therefore, the two assays were used interchangeably.

In the inhibition by syngeneic antiantiidiotypic antisera of the binding of antiidiotypic MAbs to idiotype-coated plates, ${ }^{125}$ I-labeled antiidiotypic MAbs $\left(1 \times 10^{5} \mathrm{cpm}\right)$ were preincubated with $50 \mu \mathrm{l}$ of 10-fold dilutions of syngeneic antiantiidiotypic antisera. After a 2-h incubation at $4^{\circ} \mathrm{C}$, the mixture was added to idiotype-coated plates and the incubation was prolonged for $16 \mathrm{~h}$ at $4^{\circ} \mathrm{C}$. Negative controls were performed by incubating ${ }^{125}$ I-labeled antiidiotypic MAbs with preimmune sera or with antiantiidiotypic antisera elicited with an unrelated antiidiotypic MAb. Results are expressed as percent inhibition compared with negative controls.

SDS-PAGE, Western blot, and isoelectric focusing (IEF) of antiidiotypic MAbs. They were performed using the procedures previously applied $(22,26,27)$.

Serological assays with lymphoid cells. The indirect binding assay with radiolabeled antimouse $\mathrm{Ig}$ xenoantibodies was performed as described (11). Briefly, lymphoid cells $\left(2.3 \times 10^{5}\right)$ were incubated for $2 \mathrm{~h}$ at $4^{\circ} \mathrm{C}$ with $50 \mu \mathrm{l}$ of 10 -fold dilutions of mouse serum. Then cells were washed three times with PBS and added with ${ }^{125}$ I-labeled xenoantibodies to the $\mathrm{Fc}$ fragment of murine $\operatorname{IgM}$ or of murine $\mathrm{IgG}\left(1 \times 10^{5}\right.$ $\mathrm{cpm})$. At the end of a $2-\mathrm{h}$ incubation at $4^{\circ} \mathrm{C}$, cells were washed four times with PBS and bound radioactivity was measured in a gamma counter.

Radiolabeling of lymphoid cells, indirect immunoprecipitation, and SDS-PAGE. Lymphoid cells were labeled either with ${ }^{125}$ I using the lactoperoxidase method (28) or with $\left[{ }^{35} S\right]$ methionine as described (12). Indirect immunoprecipitation and SDS-PAGE were performed as described (12).

\section{Results}

Hybridization of murine myeloma cells P3-X63-Ag8.653 with splenocytes from a BALB/c mouse immunized with the syngeneic anti HLA-DR1,4,w6,w8,w9 MAb AC1.59, an IgM, yielded 900 hybridomas. Testing of their spent medium with MAb AC1.59 in the binding assay using ${ }^{125}$ I-labeled xenoantibodies specific for murine IgG as a tracer detected activity in 108 supernatants.

The hybridomas F5-444, F5-830, F5-963, F5-1126, F5-1336, and F5-1419, which showed the highest reactivity with $\mathrm{MAb} \mathrm{AC1} .59$, were subcloned and grown in $\mathrm{BALB} / \mathrm{c}$ mice. MAbs were purified from the ascitic fluid, radiolabeled with ${ }^{125} \mathrm{I}$, and tested in a binding assay with a panel of 12 anti-HLA class I MAbs, 13 anti-HLA class II MAbs, and 9 anti-human MAA MAbs. The anti-HLA-DQw1 MAb KS-11 and the anti-HLA-DR4, DQw1 MAb KS-5 included in the panel have the same heavy and light chain isotype as MAb AC1.59. As shown in Table I, ${ }^{125} \mathrm{I}$-labeled MAb F5-444, F5-830, F5-963, F5-1126, F5-1336, and F5-1419 reacted only with MAb AC1.59. The specificity of the binding is indicated by the reactivity of antiidiotypic MAb F3-C25 only with the corresponding immunizing MAb CR11-462. The coating of plates with MAbs is indicated by the specific binding of ${ }^{125} \mathrm{I}-\mathrm{la}-$ beled goat anti-mouse Ig antibodies.

The antiidiotypic MAb F5-444, F5-830, F5-963, F5-1126, F5-1336, and F5-1419 inhibited the binding of ${ }^{125}$ I-labeled MAb AC1.59 to cultured B lymphoid cells BAE 219 (HLADR8), LG-2 (HLA-DR1), LKT-13 (HLA-DR4), THO (HLADR4), and WALK (HLA-DR4) in a dose-dependent manner. No significant difference was found among the six antiidiotypic MAbs in the amount required to inhibit by $50 \%$ the binding of ${ }^{125}$ I-labeled MAb AC1.59 to lymphoid cells with different HLA phenotypes. Representative results are shown in Fig. 1. The inhibition is specific because the antiidiotypic MAbs elicited with MAb AC1.59 did not affect the binding of ${ }^{125} \mathrm{I}-\mathrm{la}$ beled anti-HLA-DR,DP MAb CR11-462 and of ${ }^{125}$ I-labeled anti-HLA-DR,DQ,DP MAb Q5/13. Furthermore the binding to lymphoid cells of ${ }^{125} \mathrm{I}$-labeled MAb AC1.59 was not affected even by large amounts $(200 \mu \mathrm{g} / \mathrm{ml})$ of the antiidiotypic MAb F3-C25 elicited with the anti-HLA-DR,DP MAb CR11-462 (data not shown). These results suggest that the idiotopes recognized by the six MAbs are within or closely related to the antigen binding site of MAb AC1.59. The idiotopes defined by the six MAbs require the association of the heavy and light chain of MAb AC1.59 for their expression, since none of them reacted with the heavy and light chain of MAb AC1.59 isolated by SDS electrophoresis under reducing conditions. Representative results are shown in Fig. 2.

The spatial relationship of the idiotopes recognized by the MAb F5-444, F5-830, F5-963, F5-1126, F5-1336, and F5-1419 was analyzed with competition experiments. As shown in Fig. 3, the six antiidiotypic MAbs cross-inhibited each other in a dose dependent manner. All of them, but the MAb F5-963, displayed a similar inhibitory activity, as measured by the amount of cold MAb required to inhibit by $50 \%$ the binding of the other ${ }^{125}$ I-labeled MAbs (Table II). The MAb F5-963 displayed a lower inhibitory activity towards the 


\begin{tabular}{|c|c|c|c|c|c|c|c|c|c|c|}
\hline \multirow[b]{2}{*}{ MAb } & \multirow{2}{*}{$\begin{array}{l}\text { Ig } \\
\text { class }\end{array}$} & \multirow[b]{2}{*}{ Specificity } & \multicolumn{7}{|c|}{${ }^{125}$ I-labeled $\mathrm{mAb}^{*}$} & \multirow{2}{*}{$\begin{array}{l}{ }^{125} \text { I-anti-mouse } \\
\text { Ig Ab }\end{array}$} \\
\hline & & & F5-444 & F5-830 & F5-963 & F5-1126 & F5-1336 & F5-1419 & F3-C25 & \\
\hline $\mathrm{AC} 1.59$ & $\mathbf{M}$ & HLA-DR1,4,w6,w8,w9 & $80^{\ddagger}$ & 114 & 53 & 91 & 113 & 112 & -8 & 18 \\
\hline H40.242.3 & G2a & HLA-DR 1 & - & - & - & - & - & - & - & 25 \\
\hline KS5 & $\mathbf{M}$ & HLA-DR4,DQw1 & - & - & - & - & - & - & - & 30 \\
\hline KS11 & $\mathbf{M}$ & HLA-DQw1 & - & - & - & - & - & - & - & 29 \\
\hline AC6G & G2b & HLA-DQw3 & - & - & - & - & - & - & - & 22 \\
\hline B $7 / 21$ & G2a & HLA-DP & - & - & - & - & - & - & - & 21 \\
\hline $\mathrm{Q} 2 / 70$ & G1 & HLA-DR & - & - & - & - & - & - & - & 24 \\
\hline Q5/6 & G2a & HLA-DR" & - & - & - & - & - & - & - & 26 \\
\hline CR $11-462$ & G1 & HLA-DR,DP & - & - & - & - & - & - & 54 & 28 \\
\hline Q2/80 & G2a & HLA-DR,DP & - & - & - & - & - & - & - & 25 \\
\hline 127 & G2a & HLA-DR,DP & - & - & - & - & - & - & - & 24 \\
\hline 420 & G1 & HLA-DR,DP & - & - & - & - & - & - & - & 19 \\
\hline 417 & G1 & HLA-DR,DP & - & - & - & - & - & - & - & 21 \\
\hline 441 & G1 & HLA-DR,DP & - & - & - & - & - & - & - & 22 \\
\hline Q5/13 & G2a & HLA-DR,DQ,DP & - & - & - & - & - & - & - & 24 \\
\hline
\end{tabular}

${ }^{125}$ I-labeled antiidiotypic MAbs $\left(2 \times 10^{5} \mathrm{cpm} /\right.$ well $)$ were tested for their ability to bind to microtiter plates which had been coated with MAb. Coating of plates with MAb was monitored by testing with ${ }^{125}$ I-labeled goat anti-mouse Ig antibodies (Ig Ab) $\left(8 \times 10^{4} \mathrm{cpm} /\right.$ well). $\quad{ }^{*} \mathrm{The}$ antiidiotypic MAb did not bind to microtiter plates coated with anti-HLA-A2,A28 MAb CR11-351 and MAb KS2, with anti-HLA-B7, B27, Bw42, Bw54, Bw55, Bw56, Bw67, Bw73 MAb KS4, with MAb Q6/64 to a determinant restricted to the gene products of the HLA-B locus, with MAb CR1, CR 10-131, CR 10-214, CR 10-215, CR11-115, and Q1/28 to monomorphic determinants of HLA class I antigens, with anti $\beta_{2}$-microglobulin MAb NAMB-1, with MAb 149.53, 225.28, 653.25, 657.5, 763.74, 902.51 to distinct determinants of high molecular weight-melanoma-associated antigen, with MAb 345.134 to 115-kD MAA, with MAb 376.94 to $100 \mathrm{kD}$ MAA and with MAb CL203.4 to $96 \mathrm{kD}$ MAA. ${ }^{\ddagger}$ Counts per minute $\times 10^{-3}$. ${ }^{\S}$ Less than $400 \mathrm{cpm}$. " Positive with all HLA-DR allospecificities but HLA-DR7.

MAb F5-1126, F5-1336, and F5-1419. These results suggest that the MAb F5-444, F5-830, F5-963, F5-1126, F5-1336, and F5-1419 recognize the same or spatially close idiotopes of MAb AC1.59.

Two approaches were used to analyze the variable region of the antiidiotypic MAbs. In the first one, the spectrotype of MAb F5-444, F5-830, F5-1126, F5-1336, and F5-1419, all IgG1, was compared; the MAb F5-963 was not included in this

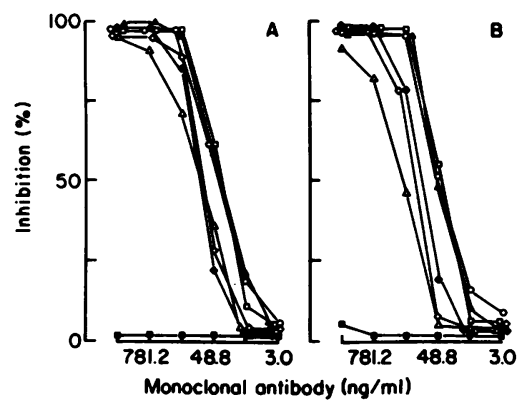

Figure 1. Inhibition by syngeneic antiidiotypic MAbs F5-444, F5-830, F5-963, F5-1126, F5-1336, and F5-1419 of the binding of MAb AC1.59 to cultured human B lymphoid cells. ${ }^{125}$ I-labeled MAb AC1.59 $\left(1 \times 10^{5}\right.$ $\mathrm{cpm} / 50 \mu \mathrm{l})$ was mixed with $50 \mu \mathrm{l}$ of fourfold

dilutions of purified unlabeled antiidiotypic MAb F5-444 (O), F5-830 $(\diamond)$, F5-963 ( $\Delta$ ), F5-1126 ( $)$, F5-1336 (), and F5-1419 (ه) (concentration ranging from 3,124 to $3.0 \mathrm{ng} / \mathrm{ml}$ ). After a 2-h incubation at $4^{\circ} \mathrm{C}$, the mixture was added to cultured human $B$ lymphoid cells LG-2 (HLA-DR1) $(A)$ and LKT-13 (HLA-DR4) $(B)$ and incubation was continued for $1 \mathrm{~h}$ at $4^{\circ} \mathrm{C}$. Then cells were washed four times with PBS and bound radioactivity was counted in a $\gamma$ counter. The antiidiotypic MAb F3-C25 to an idiotope within the antigen combining site of the anti-HLA-DR,DP MAb CR11-462 was used as a negative control (ø). analysis, since it is an IgG2a. The five antiidiotypic MAbs focus in the pH-6.0-6.6 range and comprise between two and four major components (Fig. 4). The spectrotypes of the five antiidiotypic MAbs are similar, but not identical suggesting a difference in the variable region at the level of the polypeptidic and/or carbohydrate moiety. This conclusion was corroborated by the analysis of the specificity of syngeneic antisera elicited with the six antiidiotypic MAbs. Each antiantiidio-

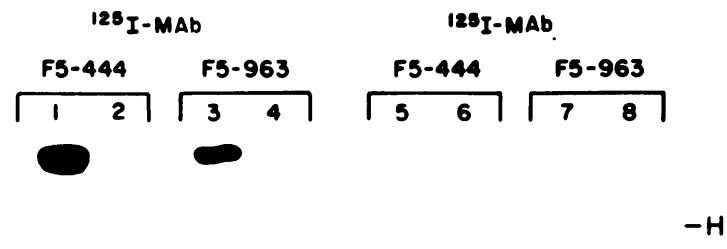

$-L$

Figure 2. Western blot analysis of the reactivity of antiidiotypic MAb F5-444 and F5-963 with MAb AC1.59. The anti-HLA-

DR1,4,w6,w8,w9 MAb AC1.59 (lanes 1, 3, 5, and 7) and the antiHLA-DQw1 MAb KS11 (lanes 2, 4, 6, and 8) were applied to an SDS gel, electrophoresed under nonreducing (lanes $1,2,3$, and 4) and reducing (lanes $5,6,7$, and 8 ) conditions and transferred to a nitrocellulose filter by electroblotting. Filters were then incubated with ${ }^{125}$ I-labeled MAb F5-444 and MAb F5-963 $\left(5 \times 10^{5} \mathrm{cpm} / \mathrm{ml}\right)$, washed and exposed to a Kodak XAR-5 film. Position of migration of heavy and light chain of Ig was detected by Ponceau red staining on a parallel track of nitrocellulose. 


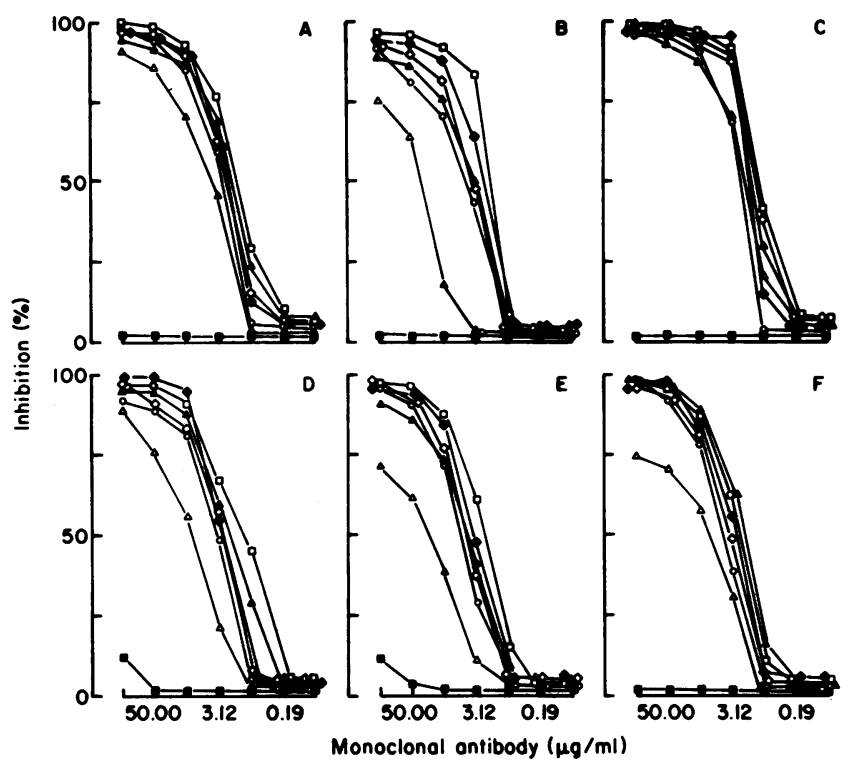

Figure 3. Mapping of idiotopes recognized by MAb F5-444, F5-830, F5-963, F5-1126, F5-1336, and F5-1419 on MAb AC1.59. ${ }^{125} \mathrm{I}$-labeled antiidiotypic MAb F5-444 $(A)$, F5-830 $(B)$, F5-963 ( $C)$, F5-1126 (D), F5-1336 $(E)$, and F5-1419 $(F)\left(1 \times 10^{5} \mathrm{cpm} / 50 \mu \mathrm{l}\right)$ were mixed with $50 \mu \mathrm{l}$ of fourfold dilutions of purified unlabeled antiidiotypic MAb F5-444 (০), F5-830 (४), F5-963 ( $\Delta)$, F5-1126 ( $)$ ), F5-1336 $(\square)$, and F5-1419 $(\Delta)$ (concentration ranging from 200 to $0.04 \mu \mathrm{g} / \mathrm{ml}$ ). After a 2-h incubation at $4^{\circ} \mathrm{C}$, the mixture was added to MAb ACl.59-coated plates and incubation was continued for an additional $16 \mathrm{~h}$ at $4^{\circ} \mathrm{C}$. Then plates were washed four times with PBS-T20 and bound radioactivity was measured in a $\gamma$ counter. The antiidiotypic MAb F3-C25 (घ) to an idiotope within the antigen combining site of anti-HLA-DR,DP MAb CR11-462 was used as a negative control.

typic antiserum was tested for its ability to inhibit the binding of each of the six ${ }^{125}$ I-labeled antiidiotypic MAbs to MAb AC1.59. As shown in Fig. 5, each antiserum inhibited the binding of the corresponding antiidiotypic MAb. Furthermore, while the anti-MAb F5-963 antiserum did not affect the binding of the other five antiidiotypic MAbs, the antisera elicited with the MAb F5-1126, F5-1336, and F5-1419 inhibited the binding of all the antiidiotypic MAbs but MAb F5-963. The latter and the MAb F5-1419 were not affected in their binding to MAb AC1.59 by anti-MAb F5-444 and anti-MAb F5-830 antisera; both of them inhibited the binding of MAb F5-444, F5-830, F5-1126, and F5-1336 to MAb AC1.59. The inhibitory activity of the anti-MAb F5-444 antiserum was higher than that of the anti-MAb F5-830 antiserum. The results suggest that the antiidiotypic MAb F5-963 does not share idiotopes with MAbs F5-444, F5-830, F5-1126, F5-1336, and F5-1419, whereas the latter five do. The idiotopes expressed by the latter five MAb appear to differ in their immunogenicity, provided that the differential reactivity patterns of the antisera do not reflect variability in the immune response of the immunized mice.

Antiantiidiotypic antisera were then tested for their content of anti-HLA class II antibodies. In a binding assay with a panel of HLA-typed lymphoid cells, only the sera from mice immunized with MAb F5-444 and F5-830 displayed specific reactivity with HLA-DR1,DR4 or DRw8 antigens bearing $B$
Table II. Mapping of Idiotopes Recognized by the Antiidiotypic MAbs F5-444, F5-830, F5-963, F5-1126, F5-1336, and F5-1419 on $M A b A C 1.59$

\begin{tabular}{|c|c|c|c|c|c|c|c|}
\hline \multirow{2}{*}{$\begin{array}{l}\text { Cold } \\
\text { MAb }\end{array}$} & \multirow{2}{*}{$\underset{\text { Isotype }}{\text { Ig }}$} & \multicolumn{6}{|c|}{${ }^{125}$ I-labeled antiidiotypic MAb } \\
\hline & & F5-444 & F5-830 & F5-963 & F5-1126 & F5-1336 & F5-1419 \\
\hline & & \multicolumn{6}{|c|}{$n g / 100 \mu l$} \\
\hline F5-444 & Gl(k) & $128^{*}$ & 195 & 109 & 281 & 281 & 225 \\
\hline F5-830 & Gl(k) & 114 & 114 & 70 & 130 & 165 & 130 \\
\hline F5-963 & G2a(k) & 201 & 1,505 & 88 & 425 & 1,119 & 362 \\
\hline F5-1126 & Gl(k) & 110 & 165 & 56 & 130 & 206 & 171 \\
\hline F5-1336 & Gl(k) & 74 & 90 & 50 & 51 & 109 & 111 \\
\hline F5-1419 & G1(k) & 88 & 156 & 62 & 105 & 236 & 111 \\
\hline F3-C25 & G2a(k) & $\mathrm{NI}^{\S}$ & NI & NI & NI & NI & NI \\
\hline AC1.59 & $\mathbf{M}(\mathbf{k})$ & 5 & 8 & 39 & 8 & 7 & 10 \\
\hline
\end{tabular}

${ }^{125}$ I-labeled antiidiotypic MAb $\left(1.0 \times 10^{5} \mathrm{cpm} /\right.$ well $)$ was preincubated for $2 \mathrm{~h}$ at $4^{\circ} \mathrm{C}$ with fourfold dilutions of purified cold antiidiotypic MAb before being added to MAb AC1.59-coated microtiter plates. After an additional $16-\mathrm{h}$ incubation at $4^{\circ} \mathrm{C}$, plates were washed four times with PBS-T20 and bound radioactivity was measured in a $\gamma$ counter.

* Concentration (nanograms/100 microliters) of purified MAb inhibiting the idiotype-antiidiotype reaction by $50 \%$.

₹ The antiidiotypic MAb F3-C25 elicited with the anti HLA-DR, DP MAb CR11-462 at the concentration of $10,000 \mathrm{ng} / 100 \mu \mathrm{l}$ did not inhibit the idiotype-antiidiotype reaction.

lymphoid cells. The reactivity pattern of the two antisera was identical to that of MAb AC1.59. Specifically, like the latter, the two antisera reacted with cells LG-2 (HLA-DR1), LKT-13 (HLA-DR4), WALK (HLA-DR4) and Yallup (HLA-DR8) (Fig. $6 \mathrm{~A}$ ). On the other hand, like MAb ACl.59, the two antisera did not react with B lymphoid cells MANN (HLADR7), Victor (HLA-DR4,w6), W1-L2 (HLA-DR4,7), and WT49 (HLA-DR3) and with T lymphoid cells MOLT-4 (Fig. 6 $B$ ). The cell lines Victor and W1-L2 express subtypes of HLADR4 and DRw6, which do not carry the determinant recognized by MAb AC1.59. The antisera did not immunoprecipitate any component from $\left.{ }^{35} \mathrm{~S}\right]$ methionine and ${ }^{125}$ I-labeled cultured B lymphoid cells LKT-13 and WALK. Furthermore, like MAb AC1.59, the antisera reacted with no $B$ lymphoid cell

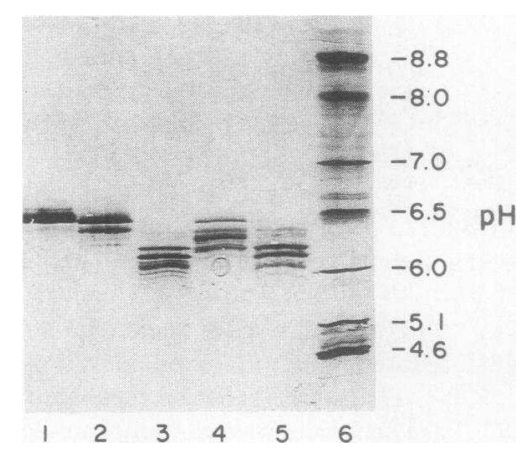

Figure 4. IEF of antiidiotypic MAb F5-444, F5-830, F5-1126, F5-1336, and F5-1419. Purified antiidiotypic MAb F5-1336 (lane 1), F5-830 (lane 2), F5-1419 (lane 3), F5-1126 (lane 4), and F5-444 (lane 5) were focused on a thin layer of $5 \%$ polyacrylamide gel in a pH gradient ranging from 3.5 to 9.5 .

Bands were visualized by Coomassie brilliant blue $\mathbf{R} 250$ staining. pH was determined by focusing a standard protein mixture (Bio-Rad Laboratories, Richmond, CA) (lane 6). 


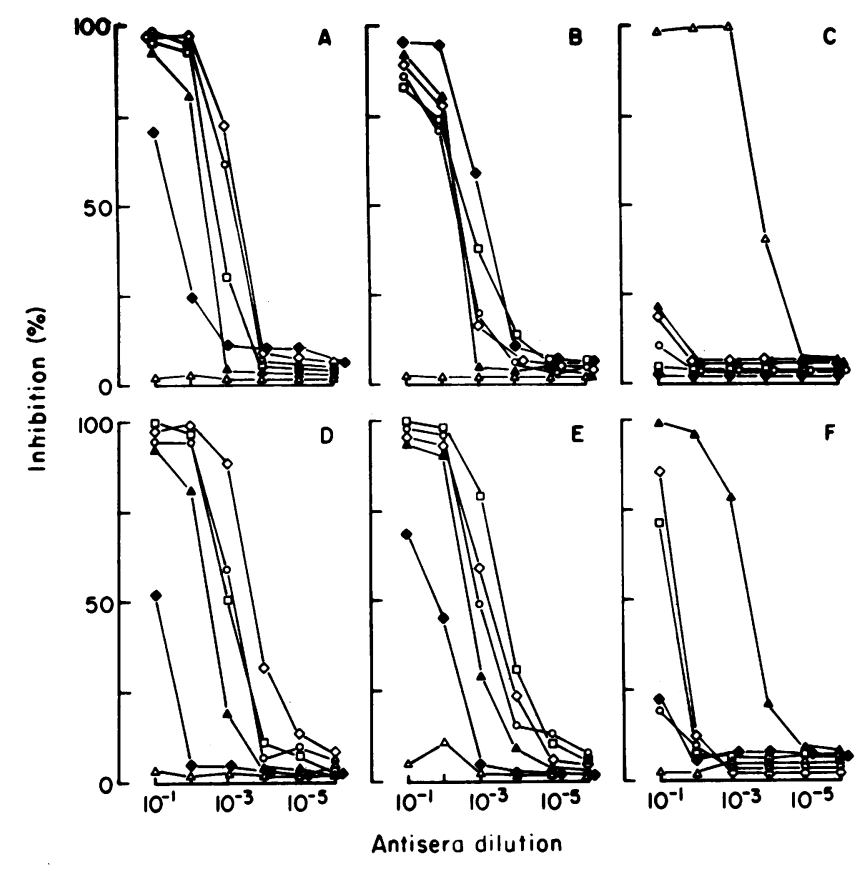

Figure 5. Inhibition by syngeneic antiantiidiotypic antisera of the binding of antiidiotypic MAb F5-444, F5-830, F5-963, F5-1126, F5-1336, and F5-1419 to MAb AC1.59. Syngeneic antisera elicited with antiidiotypic MAb F5-444, (0), F5-830 (४), F5-963 ( $\triangle$ ), F5-1126

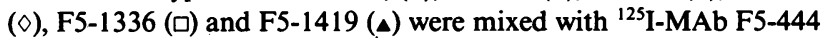
$(A), \mathrm{F} 5-830(B), \mathrm{F} 5-963(C), \mathrm{F} 5-1126(D), \mathrm{F} 5-1336(E)$, and F5-1419 $(F)$. After a 2 -h incubation at $4^{\circ} \mathrm{C}$, the mixture was added to $\mathrm{MAb}$ AC1.59-coated plates and incubation was prolonged for an additional $16 \mathrm{~h}$ at $4^{\circ} \mathrm{C}$. After four washings with PBS-T20, bound radioactivity was measured in a $\gamma$ counter.

WALK component in Western blotting. Therefore the reactivity of the antisera with HLA class II antigens was shown by measuring their binding to HLA class II antigens isolated from cultured B lymphoid cells by affinity chromatography on anti HLA-DR,DP MAb CR11-462. To this end, an extract of cultured B lymphoid cells LKT-13 (HLA-DR4), MANN (HLADR7), Victor (HLA-DR4,DRw6), and WALK (HLA-DR4) was incubated for $48 \mathrm{~h}$ at $4^{\circ} \mathrm{C}$ in 96-well microtiter plates coated with $\mathrm{F}\left(\mathrm{ab}^{\prime}\right)_{2}$ fragments of the anti-HLA class II MAb CR11-462. After four washings with PBS-T20, $50 \mu$ l of 10-fold dilutions of murine sera was added to each well and the incubation was continued for an additional $16 \mathrm{~h}$ at $4^{\circ} \mathrm{C}$. Then plates were washed four times with PBS-T20 and added with ${ }^{125}$ I-labeled xenoantibodies to the Fc fragment of mouse Ig (8 $\left.\times 10^{4} \mathrm{cpm}\right)$. After an additional 16 -h incubation at $4^{\circ} \mathrm{C}$ and five washings with PBS-T20, bound radioactivity was measured. Like MAb AC1.59, sera from mice injected with MAb F5-444 and F5-830 reacted with HLA class II antigens isolated from cultured B lymphoid cells LKT-13 and WALK, but not with those isolated from cultured B lymphoid cells MANN and Victor (Fig. 7). The reactivity is specific because the serum from a BALB/c mouse immunized with the anti-MAb CR1 1-462 MAb F3-B6 did not react with plates coated with HLA class II antigens isolated from cultured B lymphoid cells LKT-13, MANN, Victor, and WALK. The presence of HLA class II antigens in plates incubated with extracts of the four B lymphoid cells lines is shown by the binding of ${ }^{125} \mathrm{I}$-labeled MAb LGII-612.14, which reacts with a distinct and spatially
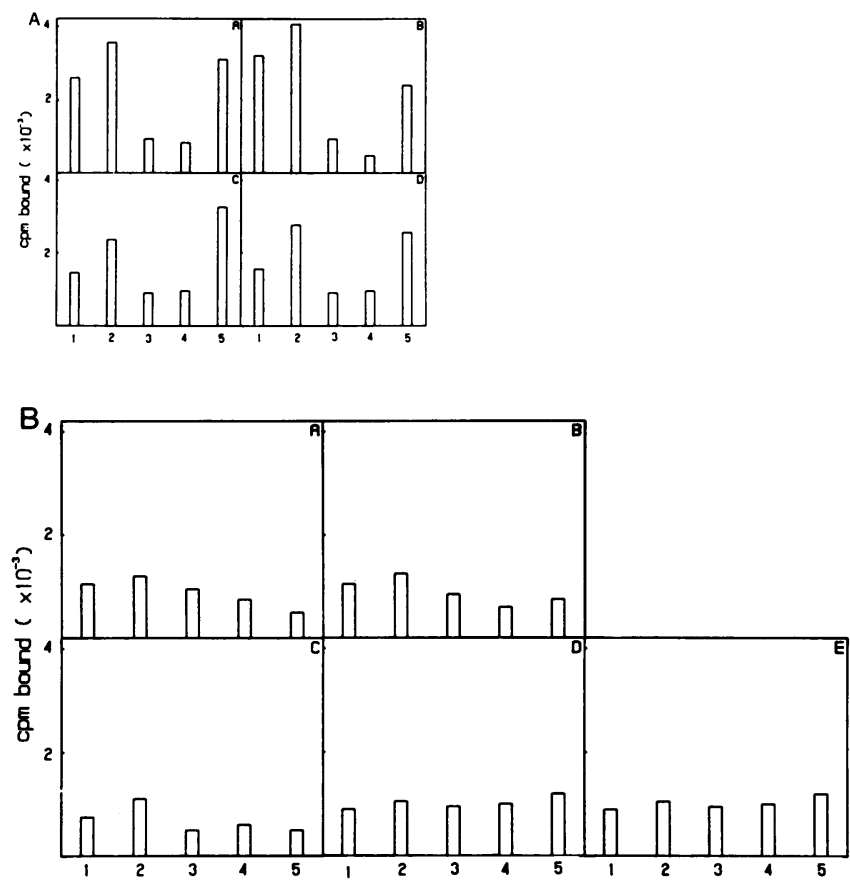

Figure 6. (A) Comparison of the reactivity with HLA-typed cultured B lymphoid cells of MAb AC1.59 and of antiantiidiotypic antisera elicited with antiidiotypic MAb F5-444 and MAb F5-830. MAb AC1.59 (50 $\mu$ l of spent medium) (column 5) and antiantiidiotypic antisera (50 $\mu$ l of a 1:50 dilution) elicited with antiidiotypic MAb F5-444 (column 1) and MAb F5-830 (column 2) were incubated for $2 \mathrm{~h}$ at $4^{\circ} \mathrm{C}$ with cultured B lymphoid cells LG-2 (HLA-DR1) $(A)$, LKT-13 (HLA-DR4) (B), WALK (HLA-DR4) $(C)$, and Yallup (HLA-DRw8) (D). Binding of antibodies to cells was measured by the uptake of ${ }^{125}$ I-labeled xenoantibodies to the Fc fragment of murine IgM and IgG. A syngeneic antiantiidiotypic antiserum elicited with the unrelated antiidiotypic MAb F3-B6 (column 3) and preimmune sera (column 4 ) were used as negative controls. (B) Comparison of the reactivity with HLA-typed cultured lymphoid cells of MAb AC1.59 and of antiantiidiotypic antisera elicited with antiidiotypic MAb F5-444 and MAb F5-830. MAb AC1.59 (50 $\mu$ l of spent medium) (column 5) and antiantiidiotypic antisera (50 $\mu$ l of a 1:50 dilution) elicited with antiidiotypic MAb F5-444 (column 1) and MAb F5-830 (column 2) were incubated for $2 \mathrm{~h}$ at $4^{\circ} \mathrm{C}$ with cultured B lymphoid cells MANN (HLA-DR7) $(A)$, Victor (HLA-DR4,w6) $(B)$, W1-L2 (HLA-DR4,7) $(C)$ and WT49 (HLA-DR3) (D) and with cultured T lymphoid cells MOLT-4 $(E)$. Binding of antibodies to cells was measured by the uptake of ${ }^{125}$ I-labeled xenoantibodies to the Fc fragment of murine IgM and IgG. A syngeneic antiantiidiotypic antiserum elicited with the unrelated antiidiotypic MAb F3-B6 (column 3) and preimmune sera (column 4) were used as negative controls.

distant determinant from the one recognized by the antiHLA-DR,DP MAb CR11-462.

To determine whether the anti-HLA class II antibodies induced by immunization with the antiidiotypic MAb F5-444 and MAb F5-830 express the corresponding idiotope, the susceptibility of the antiantiidiotypic antiserum to inhibition by antiidiotypic MAb F5-444 and F5-830 in their binding to HLA class II antigens isolated from cultured lymphoid cells LKT-13 was tested. As shown in Fig. 8, the antiidiotypic MAb F5-444 and F5-830 inhibited the binding of the syngeneic antiantiidiotypic antiserum to HLA class II antigens isolated from cultured B lymphoid cells LKT-13 in a dose-dependent 


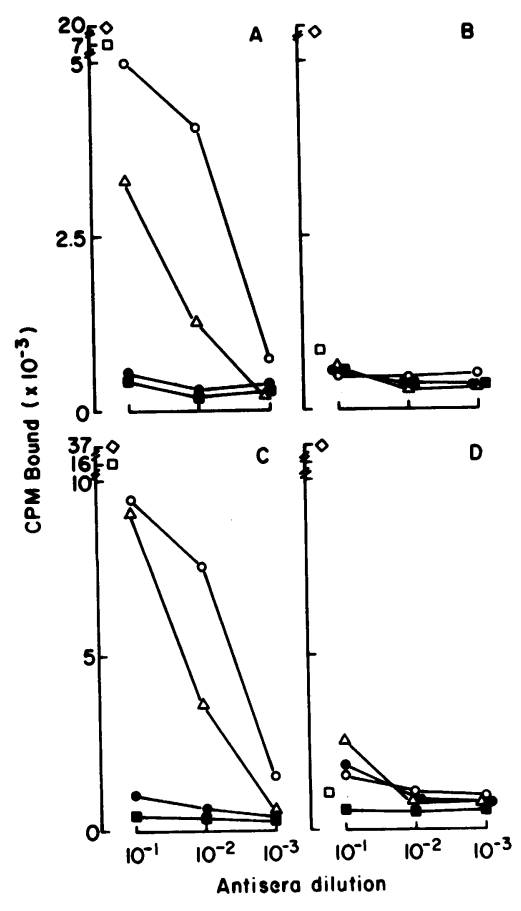

F5-444 ( $\triangle$ ) and MAb F5-830 (o). Incubation was continued for an additional $16 \mathrm{~h}$ at $4^{\circ} \mathrm{C}$. Binding of antibodies to HLA class II antigens was measured by the uptake of ${ }^{125}$ I-labeled xenoantibodies to the $\mathrm{Fc}$ fragment of murine Ig. A syngeneic antiantiidiotypic antiserum elicited with the unrelated antiidiotypic MAb F3-B6 (•) and preimmune sera (a) were used as negative controls. Coating of plates with HLA class II antigens was assessed by measuring the binding of anti-HLA-DR1,4,w6,w8,w9 MAb AC1.59 (ם) and of anti HLADR,DP MAb LG2-612.14 $(\diamond)$. The latter two MAbs recognize distinct and spatially distant determinants from the one recognized by the anti HLA-DR,DP MAb CR 11-462.

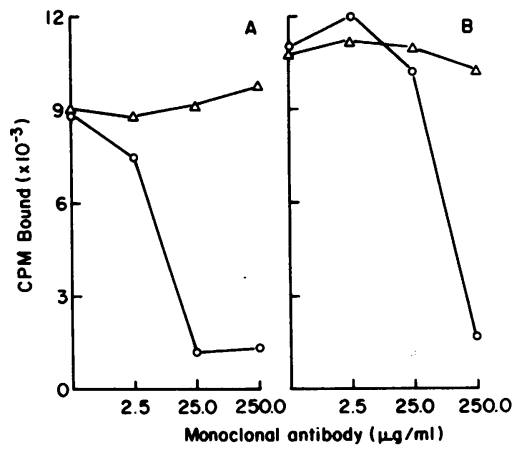

Figure 8. Inhibition by antiidiotypic MAb F5-444 and MAb F5-830 of the binding to purified HLA class II antigens of syngeneic antiantiidiotypic antisera elicited with MAb F5-444 and MAb F5-830. Syngeneic antiantiidiotypic antiserum $(50 \mu$ l of a $1: 10$ dilution) elicited with the antiidiotypic MAb F5-444 $(A)$ and MAb F5-830 $(B)$ were mixed with $50 \mu$ l of PBS containing different amounts of purified immunizing antiidiotypic MAb (O). After $1 \mathrm{~h}$ incubation at $4^{\circ} \mathrm{C}$, the mixture was added to wells coated with HLA class II antigens purified from an extract of cultured B lymphoid cells LKT-13 (HLA-DR4) by binding to $\mathrm{F}\left(\mathrm{ab}^{\prime}\right)_{2}$ fragments of MAb CR11-462. Inčubation was prolonged for an additional $16 \mathrm{~h}$ at $4^{\circ} \mathrm{C}$. Binding of antibodies to HLA class II antigens was measured by the uptake of ${ }^{125}$ I-labeled xenoantibodies to the $\mathrm{Fc}$ fragment of murine IgG. The antiidiotypic MAb T10-440 to an idiotope within the antigen combining site of anti-HLA-A2,A28 MAb CR11-351 $(\Delta)$ was used as a negative control. fashion. The inhibition is specific because preincubation with the antiidiotypic MAb T10-440 elicited with the anti-HLAA2,28 MAb CR11-351 had no effect on the binding of antiMAb F5-444 and MAb F5-830 antisera to cultured lymphoid cells LKT-13.

\section{Discussion}

This study has described for the first time the development and characterization of murine antiidiotypic MAbs to the syngeneic MAb AC1.59, which recognizes a polymorphic determinant of HLA DR antigens. The MAb F5-444, F5-830, F5-963, F5-1126, F5-1336, and F5-1419 we have investigated in details recognize private idiotopes because they react only with the immunizing MAb AC1.59 when tested with a large panel of anti-HLA class I and class II MAbs. The specificity of the antiidiotypic MAbs parallels that of antiidiotypic antisera elicited in BALB/c mice with the MAb ACl.59 (27): they displayed no cross-reactivity with a panel of anti-HLA class II MAbs. Because none of the latter displays the same specificity as MAb AC1.59, these findings are in agreement with results obtained in the murine system that only antibodies of the same fine specificity share idiotopes (29-35).

The idiotopes defined by the six MAbs require the association of the heavy and light chain of MAb AC1.59 for their expression because they do not react with isolated heavy and light chains in Western blotting. Mapping experiments and functional studies suggest that the idiotopes recognized by the six MAbs are spatially close, but not identical, as they cross-inhibit each other in their binding to MAb AC1.59, but elicit antiantiidiotypic antibodies of different or similar, but not identical specificity. Furthermore, the six antiidiotypic MAbs differ in their ability to elicit anti-HLA class II antibodies. The latter were detected only in sera from BALB/c mice immunized with antiidiotypic MAb F5-444 and F5-830. The antiHLA class II antibodies induced by antiidiotypic MAbs mimic the characteristics of MAb AC1.59 because they display the same reactivity pattern with a panel of HLA-typed B lymphoid cell lines and purified HLA class II antigens and with syngeneic antiidiotypic MAbs. The inability of antiantiidiotypic antisera to immunoprecipitate HLA class II antigens from cultured B lymphoid cells is not surprising, in view of the low intensity of components immunoprecipitated by MAb AC1.59 from radiolabeled $B$ lymphoid cells. It may reflect the low affinity and/or titer of anti-HLA class II antibodies induced by antiidiotypic MAbs in a syngeneic combination.

Antiidiotypic antibodies have been classified into four groups (36). Antibodies $\alpha$ recognize idiotopes distinct from the antigen combining site. Antibodies $\beta$ recognize idiotopes within the antigen combining site and bear the internal image of the nominal antigen. Like the former ones, antibodies $\gamma$ recognize idiotopes within the antigen combining site and therefore are antigen inhibitable. However, they do not mimic the three-dimensional structure of the nominal antigen. Antibodies $\epsilon$ recognize determinants shared by the antibodies and by the nominal antigen. According to this classification, the MAbs F5-444 and F5-830 recognize $\beta$ idiotopes because they are the mirror image of HLA class II antigens. The remaining four MAbs inhibit the interaction of MAb AC1.59 with the corresponding antigen and do not induce the formation of anti-HLA class II antibodies. Therefore, they are antiidiotypic 
antibodies $\gamma$, provided that the lack of production of anti-HLA class II antibodies by the immunized mice does not reflect individual variability in the ability to produce anti-HLADR 1,4,w6,w8,w9 antibodies following immunization with antiidiotypic MAbs. Only $\sim 20 \%$ of BALB/c mice treated with antiidiotypic xenoantibodies were found to produce anti-H-2 $\mathrm{K}^{\mathrm{k}}$ antibodies (37). Characterization of the amino acid sequence of the variable region of the six antiidiotypic MAbs elicited with MAb AC1.59 will define the structural basis of their diversity. Furthermore, this information combined with the available data about the amino acid sequence of HLADR4 antigens (38) will provide the background to synthesize peptides that can be used to modulate the immune response to these antigens. Experiments along this line are in progress in our laboratory.

In the histocompatibility antigen area, antiidiotypic antibodies that are the mirror image of antigens have been developed in three other systems. In mice-, pig-, and rabbit-antiidiotypic antibodies elicited with a murine MAb induced the formation of anti-H-2 class I antibodies in some of the BALB/ c mice treated (39), and pig-antiidiotypic antibodies elicited with a murine MAb induced the formation of anti-class II histocompatibility antigen antibodies in all the $\mathrm{C} 3 \mathrm{H}$.SW mice treated (40). In rats, like in our system, one syngeneic antiidiotypic MAb elicited the formation of anti-class II histocompatibility antigen antibodies (41). In swines, rabbit-antiidiotypic antibodies elicited with a murine $\mathrm{MAb}$ induced the formation of anti-class I histocompatibility antigen antibodies in mice, but not in swines (42). Furthermore, in these three systems, like in the human one analyzed in this investigation, antibodies elicited with antiidiotypic antibodies were shown to share idiotope(s) with the MAb used to elicit antiidiotypic antibodies.

The frequency of antiidiotypic antibodies secreting hybridomas in the fusion analyzed is noteworthy in view of the difficulties encountered to develop antiidiotypic MAbs to murine anti-HLA class II MAbs (unpublished observations). The frequency we have obtained is markedly higher than that we have obtained using splenocytes from BALB/c mice immunized with MAbs to monomorphic determinants of HLA-DR and DP antigens (18), to polymorphic determinants of HLA-DQ antigens, to monomorphic and polymorphic determinants of HLA Class I antigens (Ferrone, S., unpublished observations) and to monomorphic determinants of human high molecular weight-melanoma associated antigen (Kusama, M., T. Kageshita, Z. J. Chen, and S. Ferrone. 1989. Production and characterization of syngeneic antiidiotypic monoclonal antibodies to murine anti-human high molecular weight-melanoma associated antigen [HMW-MAA] monoclonal antibodies. Manuscript submitted for publication.) Furthermore, the frequency is markedly higher than that obtained with splenocytes from BALB/c mice immunized with syngeneic anti murine I-A MAbs (43) and from rats immunized with syngeneic and allogeneic MAbs to rat class II histocompatibility antigens (44). Whether this difference reflects the immunization schedule, the IgG class of MAb AC1.59 and/or the immunogenicity of its idiotopes remains to be determined.

The studies reported herein using antiidiotypic MAbs directed against the anti HLA-DR1,4,w6,w8,w9 MAb AC1.59 suggest that idiotype networks operate during the course of the murine immune response to HLA class II antigens. Therefore, antiidiotypic antibodies may be useful reagents to alter the serologic characteristics of an antibody response to HLA class II antigens and may offer a potential means to modulate the immune response to this antigen.

\section{Acknowledgments}

The authors wish to acknowledge the excellent secretarial assistance of Mrs. Edwina L. Jones, Mrs. Harriett V. Harrison, and Ms. Deborah O. Kimbo.

This work was supported by National Institutes of Health grant AI-21384 and by a grant from the Juvenile Diabetes Foundation International. F. Perosa is supported by a research fellowship from the Lions Clubs International Foundation, American Diabetes Association.

\section{References}

1. Jerne, N. K. 1974. Towards a network theory of the immune system. Ann. Immunol. (Paris). 125C:373-389.

2. Cosenza, H., and H. Kohler. 1972. Specific suppression of the antibody response by antibodies to receptors. Proc. Natl. Acad. Sci. USA. 69:2701-2705.

3. Hart, D. A., A.-L. Wang, L. L. Pawlak, and A. Nisonoff. 1972. Suppression of idiotypic specificities in adult mice by administration of antiidiotypic antibody. J. Exp. Med. 135:1293-1300.

4. Sy, M.-S., B. A. Bach, Y. Dohi, A. Nisonoff, B. Benacerraf, and M. I. Greene. 1979. Antigen- and receptor-driven regulatory mechanisms. I. Induction of suppressor $T$ cells with anti-idiotypic antibodies. J. Exp. Med. 150:1216-1228.

5. Thomas, W. R., G. Morahan, and J. F. A. P. Miller. 1983. Induction of suppressor $\mathrm{T}$ cells by monoclonal anti-idiotope antibody in strains of mice not expressing the idiotope in hyperimmune serum. J. Immunol. 130:2079-2082.

6. Crepaldi, T., P. Richiardi, F. Malavasi, A. O. Carbonara, M. Igarashi, and S. Ferrone. 1985. The monoclonal antibody AC1.59 defines a new polymorphic determinant on HLA-DR molecules. Tissue Antigens. 26:25-34.

7. Russo, C., A. K. Ng, M. A. Pellegrino, and S. Ferrone. 1983. The monoclonal antibody CR11-351 discriminates HLA-A2 variants identified by $\mathrm{T}$ cells. Immunogenetics. 18:23-35.

8. Quaranta, V., M. A. Pellegrino, and S. Ferrone. 1981. The monoclonal xenoantibody Q6/64 recognizes a determinant expressed by certain gene products of the A and B loci of the HLA region. Immunogenetics. 14:403-413.

9. Turco, M. C., M. De Felice, L. Corbo, G. Morrone, R. Mertelsmann, S. Ferrone, and S. Venuta. 1985. Regulatory role of a monomorphic determinant of HLA Class I antigen in T cell proliferation. $J$. Immunol. 135:2268-2273.

10. Quaranta, V., L. E. Walker, G. Ruberto, M. A. Pellegrino, and S. Ferrone. 1981. The free and the $\beta_{2}$-microglobulin-associated heavy chains of HLA-A,B alloantigens share the antigenic determinant recognized by the monoclonal antibody Q1/28. Immunogenetics. 13:285295.

11. Pellegrino, M. A., A. K. Ng, C. Russo, and S. Ferrone. 1982. Heterogeneous distribution of determinants defined by monoclonal antibodies on HLA-A and B antigens bearing molecules. Transplantation (Baltimore). 34:18-23.

12. Quaranta, V., M. A. Pellegrino, and S. Ferrone. 1981. Serologic and immunochemical characterization of the specificity of four monoclonal antibodies to distinct antigenic determinants expressed on subpopulations of human Ia-like antigens. J. Immunol. 126:548-552.

13. Wilson, B. S., K. Imai, P. G. Natali, and S. Ferrone. 1981. Distribution and molecular characterization of a cell-surface and a cytoplasmic antigen detectable in human melanoma cells with monoclonal antibodies. Int. J. Cancer. 28:293-300.

14. Imai, K., P. G. Natali, N. E. Kay, B. S. Wilson, and S. Ferrone. 
1982. Tissue distribution and molecular profile of a differentiation antigen detected by a monoclonal antibody (345.134S) produced against human melanoma cells. Cancer Immunol. Immunother. 12:159-166.

15. Imai, K., B. S. Wilson, A. Bigotti, P. G. Natali, and S. Ferrone. 1982. A 94,000 -Dalton glycoprotein expressed by human melanoma and carcinoma cells. J. Natl. Cancer Inst. 68:761-769.

16. Watson, A. J., R. DeMars, I. S. Trowbridge, and F. H. Bach. 1983. Detection of a novel human class II HLA antigen. Nature (Lond.). 304:358-361.

17. Birnbaum, D., M. Dosseto, F. Bourgue, M. Pierres, and F. M. Kourilsky. 1982. A cross-reactive mouse anti-I-E $E^{k}$ monoclonal antibody detects an HLA-DR polymorphism linked to HLA-DR1. Mol. Immunol. 19:755-764.

18. Perosa, F., and S. Ferrone. 1988. Syngeneic antiidiotypic monoclonal antibodies to the murine anti-HLA-DR,DP monoclonal antibody CR11-462. Hum. Immunol. 23:255-269.

19. Russo, C., L. Callegaro, E. Lanza, and S. Ferrone. 1983. Purification of IgG monoclonal antibody by caprylic acid precipitation. $J$. Immunol. Methods. 65:269-271.

20. Ey, P. L., S. J. Prowse, and C. R. Jenkin. 1978. Isolation of pure IgG $_{1}$, IgG2a, and IgG2b immunoglobulins from mouse serum using protein A-Sepharose. Immunochemistry. 15:429-436.

21. Perosa, F., M. Tsujisaki, and S. Ferrone. 1987. Syngeneic antiidiotypic antisera to murine monoclonal antibodies to monomorphic and polymorphic determinants of HLA Class I antigens. J. Immunol. 138:2202-2207.

22. Laemmli, U. K. 1970. Clevage of structural proteins during the assembly of the head of bacteriophage T4. Nature (Lond.). 227:680685.

23. Greenwood, F. C., W. M. Hunter, and J. S. Glover. 1963. The preparation of ${ }^{131} \mathrm{I}$-labelled human growth hormone of high specific radioactivity. Biochem. J. 89:114-123.

24. Buttin, G., G. LeGuern. L. Phalente, E. C. C. Lin, L. Medrano, and P. A. Cazenave. 1978. Production of hybrid lines secreting monoclonal anti-idiotypic antibodies by cell fusion on membrane filters. Current Topic Microbiol. Immunol. 81:27-36.

25. Perosa, F., T. Kageshita, R. Ono, and S. Ferrone. 1989. Comparison of serological methods to detect antiidiotypic antibodies. Methods Enzymol. In press.

26. Towbin, H., T. Staehelin, and J. Gordon. 1979. Electrophoretic transfer of proteins from polyacrylamide gels to nitrocellulose sheets: procedure and some applications. Proc. Natl. Acad. Sci. USA. 76:4350-4354.

27. Perosa, F., and S. Ferrone. 1987. Syngeneic anti-idiotypic antisera to murine anti-HLA Class II monoclonal antibodies. J. Immunol. 139:1232-1239.

28. Zweig, S. E., and E. M. Shevach. 1983. Production and properties of monoclonal antibodies to guinea pig Ia antigens. Methods Enzymol. 92:66-85.

29. Devaux, C., and M. Pierres. 1982. Clonal analysis of B and T cell responses to Ia antigens. III. Characterization of 12 xenogeneic anti-idiotypic antisera to A. TH-derived anti-I-A ${ }^{k}$ and anti-I- $E^{k}$ monoclonal antibodies. J. Immunol. 128:751-757.

30. Epstein, S. L., K. Ozato, J. A. Bluestone, and D. H. Sachs. 1984. Idiotypes of anti-Ia antibodies. I. Expression of the 14-4-4S idiotype in humoral immune responses. J. Exp. Med. 154:397-410.
31. Grutzman, R., and G. J. Hammerling. 1982. Idiotypic relationship of anti-Ia.2 antibodies. Eur. J. Immunol. 12:307-312.

32. Devaux, C., and M. Pierres. 1983. Analysis of the repertoire of anti-idiotypic $B$ cell responses to self-I-A ${ }^{k}$ or $\mathrm{I}^{k} \mathrm{E}^{k}$ reactive monoclonal antibodies in A.TL mice. Scand. J. Immunol. 17:375-387.

33. Melino, M. R., S. L. Epstein, D. H. Sachs, and T. H. Hansen. 1983. Idiotypic and fluorometric analysis of the antibodies that distinguish the lesion of the I-A mutant B6.C-H-2 ${ }^{\mathrm{bm} 12}$. J. Immunol. 131:359-364.

34. Bluestone, J. A., H. Auchincloss, Jr., S. L. Epstein, and D. H. Sachs. 1984. Idiotypes of anti-MHC antibodies. In Idiotypic Manipulations in Biological Systems. H. Kohler, P. A. Cazenave, and J. Urbain, editors. Academic Press, New York. 243-273.

35. Devaux, C., S. L. Epstein, D. H. Sachs, and M. Pierres. 1982. Cross-reactive idiotypes of monoclonal anti-Ia ${ }^{k}$ antibodies: characterization with xenogeneic anti-idiotypic reagents and expression in antiH-2 humoral responses. J. Immunol. 129:2074-2081.

36. Bona, C. A., and H. Kohler. 1984. Anti-idiotypic antibodies and internal image. In Monoclonal and Anti-idiotypic Antibodies. Probes for Receptor Structure and Function. J. C. Venter, C. M. Fraser, and J. Lindstrom, editors. Vol. 4. Alan R. Liss, New York. 141-150.

37. Auchincloss, H., Jr., J. A. Bluestone, and D. H. Sachs. 1983. Antiidiotypes against anti-H-2 monoclonal antibodies. $\mathrm{V}$. In vivo antiidiotype treatment induces idiotype-specific helper T cells. J. Exp. Med. 157:1273-1286.

38. Gregersen, P. K., M. Shen, Q.-L. Song, P. Merryman, S. Degar, T. Seki, J. Maccari, D. Goldberg, H. Murphy, J. Schwenzer, C. Y. Wang, R. J. Winchester, G. T. Nepom, and J. Silver. 1986. Molecular diversity of HLA-DR4 haplotypes. Proc. Natl. Acad. Sci. USA. 83:2642-2646.

39. Bluestone, J. A., S. O. Sharrow, S. L. Epstein, K. Ozato, and D. H. Sachs. 1981 . Induction of anti-H-2 antibodies without alloantigen exposure by in vivo administration of anti-idiotype. Nature (Lond.). 291:233-235.

40. Epstein, S. L., V. R. Masakowski, S. O. Sharrow, J. A. Bluestone, K. Ozato, and D. H. Sachs. 1982. Idiotypes of anti-Ia antibodies. II. Effects of in vivo treatment with xenogeneic anti-idiotype. J. Immunol. 129:1545-1552.

41. Hemmi, S., M. Fenner, E. Gall, H. Binz, and H. Wigzell. 1986. Studies of monoclonal antibodies specific for major histocompatibility complex products of the rat. IV. Production and characterization of polyclonal and monoclonal anti-anti-idiotypic antibodies. Scand. J. Immunol. 23:327-349.

42. Rabinowitz, R., M. D. Pescovitz, and D. H. Sachs. 1986. Antiidiotype to monoclonal anti-swine SLA antibody detects a common idiotype shared by mouse anti-SLA sera and elicits an anti-SLA activity. Immunology. 58:607-613.

43. Phillips, M. L., J. F. Harris, and T. L. Delovitch. 1984. Idiotypic analysis of anti-I-A $\mathrm{A}^{\mathrm{k}}$ monoclonal antibodies. I. Production and characterization of syngeneic anti-idiotypic $\mathrm{mAb}$ against an anti-I- $\mathrm{A}^{\mathrm{k}} \mathrm{mAb} . J$. Immunol. 133:2587-2594.

44. Hemmi, S., M. Fenner, H. Binz, K. Winterhalter, and H. Wigzell. 1985. Studies of monoclonal antibodies specific for major histocompatibility complex products of the rat. III. Production and characterization of syngeneic and allogeneic monoclonal anti-idiotypic antibodies to monoclonal alloantibodies. Scand. J. Immunol. 21:575-584. 